How to cite this article:

Alsaadi, S. A., Md Khalid, R., \& Wan Dahalan, W. S. A. (2020). Revisiting the human right to water in contemporary international law. UUM Journal of Legal Studies, 11(1), 37-49. https://doi.org/10.32890/uumjls.11.1.2020.6860

\title{
REVISITING THE HUMAN RIGHT TO WATER IN CONTEMPORARY INTERNATIONAL LAW
}

\section{${ }^{1}$ Saad Abbas Kadhim Alsaadi, ${ }^{2}$ Rasyikah Md Khalid \& ${ }^{3}$ Wan Siti Adibah Wan Dahalan}

\author{
${ }^{1}$ Ministry of Foreign Affairs, Iraq \\ ${ }^{2 \nless 3}$ Faculty of Law, Universiti Kebangsaan Malaysia \\ 43600 Bangi Selangor Malaysia
}

${ }^{2}$ Corresponding author: rasyikah@ukm.edu.my

Received: 15/8/2019 Revised: 9/1/2020 Accepted: 12/1/2020 Published: 31/1/2020

\begin{abstract}
The right to water has passed through many steps until it has received a full legal adoption in the international human rights law and international water law. However, there are many parties which feel that the right to water should not stand on its own as it complicates the present legal framework for international human rights. This paper examined, based on qualitative research approach, several impediments in legislating water as a human right within the purview of relevant international human rights conventions, taking into account the United Nations (UN) Agenda 2030 for Sustainable Development Goals No. 3: Good Health and Well-being and Goal No. 6: Clean Water and Sanitation. The study indicates that human rights notions have been gaining influential rule in international water law, notably human right to water, which has been recognized by the UN General Assembly and the Human Rights Council (HRC). This study however concludes that despite efforts to deny the legal basis of the right to water as one of the soft law, this right remains as a basic human right and should be respected by all countries.
\end{abstract}

Keywords: International water law, Human rights, Sustainable development goals. 


\section{INTRODUCTION}

The majority of laws on the international water principle are correlated to human rights, including the principle of equitable and reasonable utilization and the principle of notification of planned measures (de Chazournes, 2013). There has long been a struggle to gain access to water, which has been considered for a long time as a "great unknown" in the human rights area (Hiskes, 2010). This is particularly valid if we recall that worldwide, 768 million people do not receive safe drinking water and around two billion people do not get adequate sanitation (Loures, Rieu-Clarke, Vercambre \& Witmer, 2015). Thus, inability to access clean and safe water resources results is an adverse impact on the communities who suffer from it, and is a violation of their basic human rights. Economic development cannot be sustained without providing access to clean water since uncontaminated sources of water are a precondition for economic fabrication and holistic development (Thampapillai, 2011). As such, the right to water is an integral part of the human rights instruments, particularly on non-navigational uses of international watercourses. This right is clearly adopted by the UN General Assembly, and to emphasize its significance, the Human Rights Commission (HRC) has appointed a Special Rapporteur to ensure member states' implementation of that right. This paper will elaborate and examine relevant instruments and conventions, including the Universal Declaration of Human Rights 1948 and the UN Mar del Plata Action Plan 1977, and investigate the legal foundation of the human right to water in international law.

\section{WATER AS A HUMAN RIGHT: AN OVERVIEW OF THE SIGNIFICANT INTERNATIONAL FORA}

The Universal Declaration of Human Rights 1948 held in Paris can be seen as the earliest attempt to incorporate the right to water as part of human rights. Water is a basic necessity for all humankind and all living creatures on earth. This was also a topic of discussion at the United Nations Conference on the Human Environment in 1972, the 1977 United Nations Water Conference in Mar del Plata, and the Ministerial Conference on Drinking Water Supply and Environmental Sanitation in 1994. 
During these conferences, important resolutions were made for improving water development for agriculture and for safe drinking water and sanitation. However, there were no definite resolution that every human has "the right to clean water and sanitation." The right to safe drinking water for instance had also been discussed but only partially within "the right of everyone to an adequate standard of living" in the International Covenant on Economic, Social and Cultural Rights 1966.

Considering how the assessment of water resources will be burdensome to developing countries, many developing states stressed on international cooperation in training programs and facilities. This is pertinent since many rivers are polluted due to unsustainable development (Mohamad, 2018). In 2004, the Bonn Charter for Safe Drinking Water proposed a set of key principles for better management and reliable provision of safe drinking water. These principles included management of the whole water supply chain, close cooperation between stakeholders and redefining the roles and responsibilities of agencies in delivering safe drinking water.

International human rights law necessitates specific commitments towards ensuring better water resources management. In this regard, states gathered at the International Conference on Water and the Environment 1992 in Dublin and agreed to the formation of the famous Dublin principles. It emphasized on a participatory and holistic water management and from there, concepts such as Integrated Water Resources Management (IWRM) and Integrated River Basin Management (IRBM) were developed. Although these concepts are concerned with sustainable development of river basins, they will eventually ensure sufficient supply of water and sanitation to all humans.

In 1992, the UN Conference on Environment and Development in Rio de Janeiro produced an important publication called 'Agenda 21 ' to promote sustainable management of natural resources by the international community (United Nations, 1992). Chapter 8 of Agenda 21 discusses water quantity and quality, surface and groundwater. It lays down strategies concerning water resources assessment, protection of water resources, water quality and aquatic ecosystem. 
It also proposes programs that link water and development for potable and non-potable use for individuals, industry, development and agriculture. However, Agenda 21 emphasizes on community participation in the activities by local authorities. In addition, Chapter 8 can only be properly executed in states including Australia which has devolved the power to provide water supply to their local authorities.

The World Summit on Sustainable Development Rio+10 was held in Johannesburg in 2002. It emphasized the facilitation of access to public information and participation in decision-making regarding water management. The Johannesburg Plan of Implementation, amongst others, requires countries to develop their own IWRM plan (United Nations, 2002). Although the right to clean was not clearly stipulated, if all states can incorporate the IWRM initiatives in their water sector, the human right to water will be satisfied through the sufficient supply of clean water and sanitation.

In 2012, the Rio+20 Summit published a document entitled "The Future We Want". In this document, a special section with five paragraphs was dedicated to water and sanitation. Paragraph 119 stresses on the inextricable link between water and sustainable development, while Paragraph 120 urges countries to implement IWRM as agreed in the Johannesburg summit. Interestingly, Paragraph 121 reaffirms international commitments towards the growing need for human right to safe drinking water and sanitation. Thus member states need to support initiatives under the UN International Decade for Action, "Water for Life", 2005-2015. The other three paragraphs consist of: Paragraph 122 which discusses the ecosystem approach to water; Paragraph 123 concerns flood, drought, scarcity, supply and demand while Paragraph 124 focuses on pollution and water quality (United Nations, 2012).

States must also ensure adequate access to a sufficient amount of safe drinking water for personal and domestic uses which include potable use and non-potable use such as sanitation, washing, and cooking. The UN Committee on Economic, Social and Cultural Rights (UNCESCR) emphasizes that access to clean water is a human right because it is indispensable for leading a life in human dignity and a prerequisite to the realization of all other human rights 
(United Nations Human Rights, 2002). This right includes the right to continuous water supplies free from arbitrary disconnection or contamination, and access to water infers physical, economic and non-discriminatory accessibility.

It is apparent that much commitment has been made to address the importance of water in the development process of a state from the birth of the United Nations to Rio+20. However, more effort is needed from developing countries to implement their pledges in their respective territories, and this must be supported by the developed countries. Today, the right to water and sanitation has been established as part of the UN Agenda 2030 for Sustainable Development Goals, especially Goal No. 3: Good Health and Wellbeing and Goal No. 6: Clean Water and Sanitation. This requires States to further their efforts in guaranteeing this right under their constitution or any other national law. Despite the establishment of the above, there are still issues in incorporating such rights in the human rights legal framework as seen in many parts of the world.

\section{THE RIGHT TO WATER AS PART OF THE HUMAN RIGHTS FRAMEWORK}

States have three implicit obligations, namely to respect, to protect, and to fulfill. The obligation to respect calls that States' legal frameworks should refrain from interfering in people's right to access water and sanitation and protect it accordingly from any breaches (United Nations Water, 2019). The obligation to fulfill includes obligations to facilitate, provide and promote access to water. The human right to water and sanitation obliges the State as a whole unit, which means that all public and private entities in a State are bound to that duty.

The State as a subject of international law remains responsible if it chooses to involve the private sector in water services provisions while only the nature of its obligation shifts, from the obligation to respect to a stronger focus on the obligation to protect (Riedel, 2005). Based on the international commitment stated above, States should respect the right to water in the process of allocation of water resources to satisfy all people's basic need for water, and must not 
redirect these resources for other purposes such as industrial uses. Water must be provided in a sufficient quantity with acceptable quality, as well as be physically and economically accessible (Winkler, 2012).

In contrast, there are counter arguments that the State is compelled to ensure that sufficient water resources are available to cultivate agricultural products to sustain its population. This obligation relies on the right to food, not to the right to water, which obviously aims at the realization of the right to food to be considered in the context of this human right (Snell, 2014). However, the right to water is not to be essentially separated from civil and political rights, with a duty to ensure non-discrimination, especially of marginalized groups (Winkler, 2012).

Several states have actually incorporated the right to water as a constitutional right of its citizens. France has adopted Bill No. 758 which incorporates the human right to water and sanitation by placing duties on local authorities to provide free public water-fountains, toilets and showers. On another continent, South Africa passed the Constitution of 1996 which guarantees everyone the right to have access to health care services, sufficient food and water, and social security under Article 27 (1). Thus the government shall ensure such rights are met if their resources allow.

The human right to water is founded on various factors in the domestic context, including having an appropriate policy, programs and planning. McCaffrey (2016) observes that there are two "striking mismatches" in the emergence of this right within the human rights legal framework; the first mismatch is between capacities and responsibilities, and the second mismatch concerns States that have accepted the right to water as a human right, but their development level does not correspond to it. There are some claims that public international law and human rights conventions do not represent an explicit acceptance of right to water (Jolly, 2018). The United States for instance insists that there does not yet appear to be a consensus among States on the existence of the right (to water) as a matter of customary international law (McCaffrey, 2016).

Despite the above, international instruments have recognized the humanitarian nature of the right to water as discussed above, namely 
the UN Mar del Plata Action Plan in 1977, the Dublin Principles, and Agenda 21, together with the Convention on the Rights of the Child (CRC) Article 24/2, and the Convention on the Elimination of All Forms of Discrimination Against Women (CEDAW). Under CEDAW, State parties are obliged to ensure women's access to adequate living conditions, particularly in relation to water supply, while the CRC requires states' parties to provide adequate nutritious food and clean drinking water (Bulto, 2011). Similarly, the Convention on the Protection and Use of Transboundary Watercourses and International Lakes of 1992 has addressed human rights in its Protocol on Water and Health of 1999.

The UN Convention on the Non-Navigational Uses of International Watercourses (UNWC) of 1997 which governs international watercourses also incorporates the human right to water. Article 10 provides that no use of an international watercourse enjoys inherent priority over other uses. Paragraph 2 of that Article deals with conflict situations under Articles 5 to 7 and States "with special regard being given to the requirements of vital human needs." This was one of the main concerns of the Delft Declaration, which was adopted at a symposium held in the Netherlands in 1991 sponsored by the UN Development Program (UNDP). This Declaration gives priority to the satisfaction of human water needs, and calls for measures to achieve this aim.

Notably, the UNWC proposed the term 'vital human needs,' which means "sufficient water to sustain human life, including both drinking water and water required for the production of food in order to prevent starvation." In this way, the UNWC prioritizes "vital human needs" over any other factor of an equitable utilization approach. In contrast, Article 14 of the Berlin Rules on Water Resources of 2004 issued by the International Law Association states that the obligation to determine an equitable and reasonable use of water lies with the State, where the State is duty-bound to "first allocate waters to satisfy vital human needs."

It is observed that access to water rests on a number of basic rights, most prominently the right to an adequate standard of living. The alleged lack of precise definition of this right to water cannot be used to dispute its legally-binding nature; however, lack of enforcement 
mechanisms often defeat this human right, which is the situation faced by many States. Hence, the Special Rapporteur on the human rights to water and sanitation is making new initiative made by to move the States towards progressive realization of the human rights to water and sanitation (United Nations Water, 2020).

\section{STATES' ATTITUDE TOWARDS THE RIGHT TO WATER}

Generally, the legal basis of recognition of the right to water is twofold; the first is based on the need for an explicit expression of the right to water in international human rights law. The second is that the right to water is a part of other major rights including the right to life. Based on that view, the right can be claimed only when life is threatened by low quality or quantity of water. The right is not "self-executing" in nature; thus, when a State party fails to provide clean water, it would not be necessarily in breach of an international obligation.

In contemporary international law, the obligation of States on the human right to water has a "due diligence" nature as opposed to absolute obligation which could be immediately enforceable. Hence, a State or an individual is not required to prove that the appropriate measures have not been followed since there is a "general agreement" that the burden of proof lies with the respective States. The concept of due diligence has obviously been defined according to the UN in the context of human rights as "an ongoing management process that a reasonable and prudent enterprise needs to undertake, in light of its circumstances 'including sector, operating context, size and similar factors' to meet its responsibility to respect human rights" (UNHROHC, 2012).

Brownlie (2003) claims that most human rights elements are part of the customary law obliged to all of the international community members, regardless of being parties to human rights treaties, unless they behave as persistent objectors against the formation process. Since human needs and habits for the use of water resources are governed by a standard of reasonableness, the question, to what extent is the right to water a part of customary international law arises (Vick, 2012). This is because States which have not ratified 
the respective human rights agreements are bound by customary law on the human right to life, which includes the right to clean water (Rudolf, 2007). As such, the vision of human needs as integrated within the right has gained an increasingly prominent role in the field of international law (de Chazournes. 2013).

International jurisprudence and tribunals have significantly contributed to ensuring the right to water via the most prestigious judicial institution, the International Court of Justice (ICJ) in the Case Concerning Kasikili/Sedudu Island (Botswana v. Namibia) 1996 and the Case Concerning the Gabcikovo-Nagymaros Project (Hungary/Slovakia) 1997. In the latter case, the ICJ Vice President, Judge Weeramanty opined that damage to the environment can impair and undermine all the human rights spoken of in the Universal Declaration and other instruments.

\section{THE ROLE OF THE UN GENERAL ASSEMBLY AND THE HUMAN RIGHTS COMMISSION (HRC) IN ADOPTING THE RIGHT TO WATER}

All previous endeavours in safeguarding the right to water were equipped with organizational support from relevant UN bodies. In 2006, the HRC requested the Office of the UN High Commissioner for Human Rights to submit "a detailed study on the scope and content of the relevant human rights obligations related to equitable access to safe drinking water and sanitation under international human rights instruments" with the affirmation of some human rights instruments. These include the UDHR, specifically General Comment No. 15 (2002) of CESCR and Articles 11 and 12 of the International Covenant on Economic, Social and Cultural Rights, which includes the right to an adequate standard of living and the right to health. Consequently, in 2007, the former High Commissioner for Human Rights stated that the right to access of safe drinking water and sanitation are equal and non-discriminatory for both potable and non-potable uses.

The HRC considered the requested report and issued a resolution in March 2008, which brought about an important step by appointing an independent expert on the issue of "human rights obligations 
related to access to safe drinking water." The HRC has drawn its mandate under Resolution 7/22 (2008) to develop a dialogue with the related parties, both public international and domestic law subjects, to identify best practices to access safe drinking water and sanitation, and to work further on clarification of the content of human rights obligations by taking into consideration non-discrimination obligation concerns (Tanzi, 2010). In 2010, the HRC appointed Ms. Catarina de Albuquerque as the first Special Rapporteur on the Human Rights to Safe Drinking Water and Sanitation, which was initially founded by the HRC in 2008 as Independent Expert on the issue. The Special Rapporteur's outcomes focused on ensuring water affordability and urged for intervention to fix a reasonable price for water supply provision.

The HRC stands on three analytical elements to recognize the human right to water. The first relies upon the derivation of a right to water from Article 11 of the International Covenant on Economic, Social and Cultural Rights (ICESCR). The second element is based on the centrality and essentiality of water to other ICESCR rights under its Article $1 / 2$, and the right to the highest attainable standard of health in Article 12/1, since water is central to environmental hygiene, as well as the necessity of water to the right to adequate food and housing in Article 11/1. The third element is a prior recognition of the right to water by other human rights instruments under international conventions, including the CRC and CEDAW (Cahill, 2010). This is also relevant under international humanitarian law, particularly the 1949 Geneva Conventions in relation to civilians in times of war and the treatment of prisoners of war (Rohaida \& Tareq, 2011).

Finally, but most importantly, the most prominent multilateral mobilization platform represented by the UN General Assembly had taken a bold step by adopting its resolution entitled "The Human Right to Water and Sanitation" in 2010 to recognize the right to safe and clean drinking water and sanitation as a human right that is essential for the full enjoyment of life and all human rights. This was concrete action followed by an elaborated, specified and comprehensive one later by the HRC two months later in September 2010 to affirm that the human right to safe drinking water and sanitation is derived from the right to an adequate standard of living and inextricably related to the right to the highest attainable standard of physical and mental 
health, as well as the right to life and human dignity (Salman, 2012). The HRC confirmed that this recognition is derived from the basic human right to health and adequate standard of living.

\section{CONCLUSION}

The formal recognition of the human right to water through the UN General Assembly and the HRC reflects a great stride forward in this context, where these resolutions illustrate clearly that this right is now founded under international law. However, this does not mean that all challenges to implementation have been resolved, as they are still absent in the domestic legislation of most countries. Hence, it fails to reflect an important international obligation. It is worth noting that merging these rights within the domestic sphere will involve additional financing commitments. This is because State parties are obliged to maximize their available resources and give room for participation of non-state actors in this context. Although the human right to water exists under international law, the gap in implementation is widened by the steady growth in population and the unsustainable management of water resources worldwide. Further, there is a crucial need to urge the Special Rapporteur to give attention to the international dimensions of the right to water. This is because the States could argue that due to various reasons including political or economic instability, the States are unable to provide water to all citizens.

\section{ACKNOWLEDGEMENTS}

This research is funded by Universiti Kebangsaan Malaysia (Grant No: GUP-2018-067).

\section{REFERENCES}

Brownlie, I. (2003). Principles of public international law (6th ed.). Oxford: Oxford University Press.

Bulto, T. S. (2011). The emergence of the human right to water in international human rights law: Invention or discovery. Melbourne Journal of International Law 12, 290. 
Cahill, A. (2010). Protecting rights in the face of scarcity: The right to water. In Mark Gibney \& Sigrun Skogly. Universal Human Rights and Extraterritorial obligations. Pennsylvania: University of Pennsylvania Press.

Case Concerning the Gabcikovo-Nagymaros Project (Hungary/ Slovakia). (1997). Judgement of 24 September 1997. International Court of Justice.

Case Concerning Kasikili/Sedudu Island (Botswana v. Namibia). (1996). Order of 24 June 1996. International Court of Justice.

de Chazournes, L. B. (2013). Fresh Water in International Law. United Kingdom: Oxford University Press.

Hiskes, R. P. (2010). Missing the green: Golf course ecology, environmental justice, and local "fulfillment" of the human right to water. Human Rights Quarterly, 32.

Jolly, S. (2018). A legal analysis of linking human right approach to access to water and sharing of trans-boundary rivers in South Asia. In Kaul J.L. \& Anupam, J. Shifting Horizons of Public International Law. New Delhi: Springer.

Loures, F., Rieu-Clarke, A., Vercambre, M. \& Witmer, L. (2015). Everything you need to know about the UN Watercourses Convention. United Nation: WWF International.

McCaffrey, C. S. (2016). The human right to water: A false promise. The University of Pacific Law Review. 47, 221.

Mohamad, A. B. (2018). The provisions of water and garbage pollution in street, drainage and building Act, 1974: A view in Islamic law. UUM Journal of Legal Studies, 9, 1-21.

Riedel, E. (2005). The human right to water chapter. In K. Dicke, St. Hobe, K.-U. Meyn, A. Peters, E. Riedel, H.-J. Schütz, Ch. Tietje, Weltinnenrecht - Liber amicorum Jost Delbrück. Berlin: Duncker \& Humblot.

Rohaida, N., \& Tareq, H. (2011). Fallujah Battles: Violations of the International Humanitarian Law. UUM Journal of Legal Studies, 2, 39-64.

Rudolf, B. (2007). Menschenrecht Wasser - Herleitung, Inhalt, Bedeutung, probleme'. In B. Rudolf., Menschenrecht Wasser? Frankfurt am Main. Peter Lang.

Salman, M. A. (2012). The human right to water - Challenges of implementation. American Society of International Law Proceedings. 44, 106. 
Snell, K. (2014). Can water be a human right? Appeal: Review of Current Law \& Law Reform, 19, 131.

Tanzi, A. (2010). Reducing the gap between international water law and human rights law: The UNECE protocol on water and health. 12 International Community Law Review. 267.

Thampapillai, V. (2011). International water law for transboundary resource management - Environmental and human rights. Environmental Policy \& Law. 41, 127.

United Nations. (1992). United Nations Conference on Environment and Development. https://sustainabledevelopment.un.org/ milestones/unced (assessed April 1, 2019).

United Nations. (2002). World Summit on Sustainable Development (WSSD), Johannesburg Summit. https:// sustainabledevelopment.un.org/milesstones/wssd (assessed April 1, 2019).

United Nations. (2012). United Nations Conference on Sustainable Development, Rio+20. https://sustainabledevelopment. un.org/rio20 (assessed April 1, 2019).

United Nations Human Rights. (2002). Committee on Economic, Social and Cultural Rights. https://www.ohchr.org/en/ hrbodies/cescr/pages/cescrindex.aspx (assessed April 1, 2019).

United Nations Water. (2019). Human Rights to Water and Sanitation. https://www.unwater.org/water-facts/humanrights/ (assessed April 1, 2019)

United Nations Water. (2020). Progressive realization of the human rights to water and sanitation. https:/www.unwater.org/ progressive-realization-of-the-human-rights-to-water-andsanitation/ (assessed April, 1, 2020)

Vick, J. M. (2012). The law of international waters: Reasonable utilization. Chicago-Kent Journal of International \& Comparative Law, 12, 141.

Winkler, I. T. (2012). The Human Right to Water: Significance, Legal Status and Implications for Water Allocation. Oregon: Oxford and Portland. 